\title{
Taşkın Frekans Analizinde Eşik Üstü Pikler Yönteminin Seyhan Havzası'nda Uygulanması
}

\author{
Gülay Onuşluel Gül1 ${ }^{*} \oplus$, Ali Gül1 ${ }^{1}$ \\ ${ }^{1}$ Dokuz Eylül Üniversitesi, Mühendislik Fakültesi, Inşaat Mühendisliği Bölümü, 35160, İmir.

\section{Özet}

Taşkın frekans analizi; nehirlerdeki belirli tekerrürlere veya olasılıklara karş̧ gelen akım miktarlarını elde edebilmek için kullanılan bir yöntemdir. Bu yolla hidrolik yapıların projelendirilmesi ve ekonomik olarak değerlendirilmesi sağlanmaktadır. Bu çalışmada Seyhan Havzası'nda yer alan 1801 no'lu istasyon için eşik üstü pik değerleri kullanılarak taşkın frekans analizi gerçekleştirilmiştir. Eşik değer; eşik değer seçme grafiği, ortalama kalıntı ömrü grafiği, yayllım indeksi grafiği ile ortalama ve standart sapmaya bağlı yöntem olmak üzere dört farklı yöntemle belirlenmiș ve elde dilen eșik üstü piklerin bağımsız olup olmadıkları otokorelasyon analizi ile sınanmıştır. Bir sonraki adımda, kısmi süreklilik serilerinde sıklıkla kullanılan Genelleştirilmiş Pareto dağılımı uygulanarak gözlenmiş değerlere uygunluğu sınanmıștır. Genelleștirilmiș Pareto dağılımının parametrelerinin ve hesaplanan 2, 5, 10, 25, 50, 100, 200, 500 ile 1000 yll tekerrürlü taşkın debileri üzerinden güven aralıklarının belirlenmesiyle belirsizlik analizi yapılmıştır. Son olarak farklı tekerrürler için hesaplanan taşkın debilerinin, yıllık maksimum değerler üzerinden elde edilen aynı tekerrürlü taşkın debileri ile karşılaştırılması gerçekleştirilmiştir. Elde edilen sonuçlara göre eşik üstü piklerin analizi ile elde edilen taşkın tahminlerinin yıllık maksimumların analizi ile elde edilen taşkın tahminlerine kıyasla düşük tekerrür aralıklarında daha büyük farklar gösterdiği, büyük tekerrürlerde ise (500 ve 1000 yıl) nispeten yakın sonuçlara ulaşıldığı görülmüştür.

\section{Anahtar Sözcükler}

Taşkınlar, Taşkın Frekans Analizi, Eşik Üstü Pikler, Kısmi Süreklilik Serileri

\section{Application of Peaks Over Threshold Method in Flood Frequency Analysis in Seyhan Basin}

\begin{abstract}
Flood frequency analysis is a statistical method that is used to obtain the amounts of flow corresponding to certain recurrences or probabilities in rivers. In this way, the design and economic evaluation of hydraulic structures is provided. In this study, flood frequency analysis was performed for the station numbered 1801 and located in Seyhan Basin by using peak values over an assigned threshold. Threshold value was determined through four different methods that include threshold selection plot, mean residual life plot, dispersion index plot as well as the method based on the mean and standard deviation; and autocorrelation analysis has been tested to determine whether the peaks obtained above the threshold are independent. Generalized Pareto distribution which is frequently used in partial duration series was applied and tested against the historically observed series. Uncertainty analysis was performed by determining the parameters of the Generalized Pareto distribution and the confidence intervals over the calculated flood flows of 2, 5, 10, 25, 50 100, 200, 500 and 1000 years. Finally, flood quantities with the recurrence intervals of 2, 5, 10, 25, 50, 100, 200, 500 and 1000 years were computed and compared to the corresponding quantities obtained from the annual maximum series. According to the results, it was observed that, the differences between the flood estimates obtained by peaks over threshold method and the analysis of annual maximums were bigger for the smaller recurrence intervals and the differences were relatively small for large recurrence intervals (500 and 1000 years).
\end{abstract}

\section{$\underline{\text { Keywords }}$}

Floods, Flood Frequency Analysis, Peaks Over Threshold, Partial Duration Series

\section{Giriş}

Taşkın frekans analizi, köprü, menfez, dolu savak ve seddeler gibi su yapılarının projelendirilmesi ve ekonomik olarak değerlendirilmesinde oldukça önemli bir yer tutmaktadır. Taşkın frekans analizi ile bahsi geçen hidrolik yapıların uygun tasarım kriterlerinin saptanması için gerekli olabilecek belirli tekerrürlü olası bir taşkın büyüklüğünün veya belirli büyüklükte bir taşkının frekansının tahmin edilmesi mümkün olabilmektedir. Taşkın büyüklüklerinin tahmininde çoğunlukla bir yıl içinde gözlenen en büyük taşkın debileri, başka bir ifadeyle yıllık maksimum seriler incelenmektedir. 
Kullanılan bir diğer seri türü de bazı araştırmacılar tarafından kısmi süreklilik serileri olarak da ifade edilen eşik üstü pikler olmaktadır. Yıllık maksimum seriler, incelenen süre kadar veriye sahipken; eşik üstü pik serileri belirlenen bir eşik değerin üstünde kalan bütün taşkın değerlerini içermektedir.

Taşkın frekans analizinde karşılaşılan en büyük problemlerden biri yıllık maksimum seriler ile eşik üstü pik serilerinden hangisinin kullanımının tercih edilmesi yönündedir. Yıllık maksimum serilerde her yıl için sadece tek bir taşkın değeri göz önüne alınmaktadır. Fakat bazı durumlarda bir yıl içinde gözlenmiş ikinci en büyük taşkın değeri diğer yıllardaki yıllık maksimum taşkınların çoğundan daha büyük olabilmekte ve yıllık maksimum seri yaklaşımı ile bu önemli durum göz ardı edilmektedir. Yıllık maksimum serilerde eşik üstü pik serileri ile karşılaştırıldığında incelenen yıllar temelinde her yıla ait birer adet veri olmak üzere daha az sayıda verinin kullanılmasına dayalı kısıtlı veri uzunluğu istatistiksel açıdan bir diğer problem olmaktadır. Eşik üstü pik serilerinin taşkın frekans analizinde kullanılması çok daha uygun görülmekle birlikte, bu serilerde karşılaşılan en büyük sorun ise taşkın piklerinin bağımsız bir zaman serisi olamayabileceği yönündedir (Rosbjerg ve Madsen 1992a).

Eşik üstü pik serilerin frekans analizinde eşik değerin belirlenmesi, ilgili analizlerin gerçekleştirilmesinde oldukça önemli rol oynamaktadır. Çok yüksek bir eşik değerin seçilmesi, yanlılığın azalması fakat eşik değerin üzerinde sayıca az değerin kalması nedeniyle varyansın artmasına sebep olmaktadır. Çok düşük bir eşik değerin seçilmesi ise gözlenmiş taşkın değerlerinin sayıca artması ve varyansın azalmasına, bununla birlikte yanlılığın da artmasına neden olmaktadır. Eşik üstü pikler (EÜP) yöntemine dayanan taşkın frekans analizleri üzerine yapılan araştırmalar, Genelleştirilmiş Pareto (GP) dağılımının kullanımı üzerine yoğunlaşmıştır. Davison ve Smith (1990) EÜP taşkın verisinin kullanılması durumunda bu yöntemin çok sayıda avantajlara sahip olduğunu belirtmiş, GP yaklaşımının pratikte kullanılması açısından EÜP yönteminin teorisi üzerine bir tartışma başlatmışlardır. GP parametrelerinin tahmini Hosking ve Wallis (1987), Wang (1991) ile Rosbjerg vd. (1992b) tarafından çalışılmıştır. Rosbjerg vd. (1992b) hidrolojideki çok sayıda uygulamalar için klasik üssel modelin ortalama hata kareleri toplamı göstergesinin Pareto yöntemine göre daha iyi sonuçlar vereceği sonucuna varmıştır. Çünkü bu yöntemde tahmin edilecek sadece bir parametre bulunmaktadır (Lu ve Stedinger 1992a; Lu ve Stedinger 1992b). Üssel model üzerine son çalışmalar Rasmussen (1991) ve Buishand (1989) tarafından yapılmıştır. Öte yandan Ekanayake ve Cruise (1993), Weibull dağılımının üssel dağılıma göre daha çok tercih edilebilir olduğunu göstermiştir. Son yıllarda yapılan ve eşik üstü pikler ile maksimum serilerin karşılaştırılmasına esas çalışmalardan bir örnek Bezak vd. (2014) tarafından Slovenya'da Sava akarsu havzasındaki Sava Nehri üzerinde yer alan Litija 1 akım istasyonu verileri üzerinden gerçekleştirilmiştir. Bu çalışmada, parametre tahmininde L-momentler yönteminin momentler ve maksimum olabilirlik yöntemlerine göre daha iyi bir performans gösterdiği, eşik üstü pikler yönteminin de daha iyi sonuçlar verdiği sonucuna varmışlardır. Silva vd. (2016) tarafından Brezilya'da yapılan bir başka çalışmada da, iklim değişkenliği nedeniyle durağan olmayan koşullar altında GP dağılımı kullanılarak eşik üstü pikler yöntemiyle taşkın frekans analizi gerçekleştirilmiştir. Diğer yandan Lang vd. (1999) tarafından yapılan çalışmada EÜP yöntemi ile yıllık maksimum serilerin analizi karşılaştırılmış, EÜP yönteminin avantajlarına rağmen, eşik değerin seçiminde yaşanan problemler ve bu yöntemin uygulamada kullanılabilmesi için genel bir kılavuz eksikliğinin olması nedenleri ile taşkın frekans analizinin hem yıllık maksimum seriler hem de eşik üstü pik serileri ile yapılması önerilmiştir.

Ülkemizde, Haktanır (1991) Türkiye'deki 23 havzada gözlem süresi 21 yıldan fazla olan 112 istasyondaki verilere dayanarak, taşkınlar için istatistiksel modeller ortaya koymuştur. Önöz (1994, 1996), Önöz ve Bayazıt (1995, 2001), taşkınların olasılık dağılımları ve uygulanan istatistiksel testlerle ilgili çalışmalar yapmışlardır. Bayazıt vd. (1997) Genelleştirilmiş Ekstrem Değer dağılımını taşkın serilerine uygulamışlardır. Önsoy (2002), Doğu Karadeniz'deki taşkınları incelemiş ve çözüm önerileri sunmuştur. Şorman (2004) tarafından yapılmış olan çalışmada, Batı Karadeniz'de klasik parametre tahmin yöntemleri (momentler yöntemi, maksimum olabilirlik yöntemi), ve olasılık ağırlıklı momentler yöntemleri ile karşılaştırmalı bölgesel frekans analizi yapılmıştır. Bayazıt ve Önöz (2004) Türkiye'deki en büyük taşkınların zarf eğrilerini belirlemiş ve bölgesel taşkın frekans analizi ile ilgili çalışmalar gerçekleştirmişlerdir. Topaloğlu (2005) tarafından Doğu Akdeniz Bölgesi'nden seçili havzalarda, Anlı (2006) tarafından Giresun Aksu Havzası'nda, Anlı vd. (2007) tarafından Göksu Havzası'nda, Büyükkaracığan ve Kahya (2007) tarafından Konya Havzası'nda, taşkın frekans analizleri gerçekleştirilmiştir. Bölgesel taşkın frekans analizi konusunda ülkemizde birçok uygulanmakla bulunmaktadır. Seckin vd. (2011) Türkiye'de 543 gözlem istasyonunda, Saf (2009) Batı Akdeniz Nehir Havzalarındaki 47 istasyon bazında yaptıkları çalışmalarda, hidrolojik olarak homojen bölgeleri araştırmış ve dağılım parametrelerinin hesaplanmasında L-momentler yöntemini kullanarak, indeks taşkın yöntemi ile bölgesel taşkın frekans analizini gerçekleştirmiştir. Şarlak ve Tiğrek (2016) çalışmalarında Göksu Nehri üzerinde yapılması planlanan Kayraktepe Barajı örneğinde taşkın frekans eğrilerinin parametrik olmayan K en yakın komşu yöntemi $(\mathrm{KNN})$ ile elde etmişler ve parametrik yöntemle elde edilen sonuçlarla karşılaştırmışlardır. Parametrik olmayan yaklaşımın parametrik yaklaşıma göre gözlem değerlerine daha uygun olduğu sonucuna ulaşmışlardır.

Bu çalışmada Seyhan Havzası'nda yer alan ve konumsal açıdan havzayı temsil niteliğiyle birlikte yeterli veri uzunluğuna sahip 1801 no'lu istasyon için eşik üstü pik değerleri kullanılarak taşkın frekans analizi gerçekleştirilmiştir. Eşik değerin belirlenmesi; eşik değer seçme grafiği, ortalama kalıntı ömrü grafiği, yayılım indeksi grafiği ile ortalama ve standart sapmaya bağlı yöntem olmak üzere dört farklı yöntemle belirlenmiş ve eşik üstü serinin bağımsızlık koşulunu sağlayıp sağlamadığı kontrol edilmiştir. 
Kısmi süreklilik serilerinde sıklıkla kullanılan GP dağılımı uygulanarak gözlenmiş değerlere uygunluğu sınanmış ve model uygunluğu kontrol edildikten sonra parametrelerin 2, 5, 10, 25, 50, 100, 200, 500 ve 1000 yıl tekerrürlü taşkın debilerinin güven aralıklarının oluşturulmasıyla belirsizlik analizi gerçekleştirilmiştir. Son olarak, eşik üstü pikler yöntemi ile hesaplanan belirli tekerrürlü taşkın debilerinin, yıllık maksimum değerler kullanılarak elde edilen aynı tekerrürlü debiler ile karşılaştırması gerçekleştirilmiştir.

\section{Veriler ve Yöntem}

\subsection{Veriler}

Çalışma kapsamında günlük akım verileri kullanılan Seyhan Havzası 1801 no'lu istasyonun konumu Şekil 1'de, bu istasyona ait minimum, maksimum, ortalama $\left(\mathrm{X}_{\mathrm{ort}}\right)$, standart sapma $\left(\mathrm{S}_{\mathrm{x}}\right)$, medyan $\left(\mathrm{X}_{\mathrm{med}}\right)$, değişkenlik katsayısı $\left(\mathrm{C}_{\mathrm{vx}}\right)$, çarpıklık katsayısı $\left(\mathrm{C}_{\mathrm{sx}}\right)$ ve sivrilik katsayısını $\left(\mathrm{k}_{\mathrm{x}}\right)$ içeren temel istatistikler de sırasıyla Tablo 1'de sunulmuştur. Seçilen gözlem istasyonunda gözlem süresi boyunca kaydedilen günlük akım değerlerine ait grafik Şekil 2'de verilmektedir.

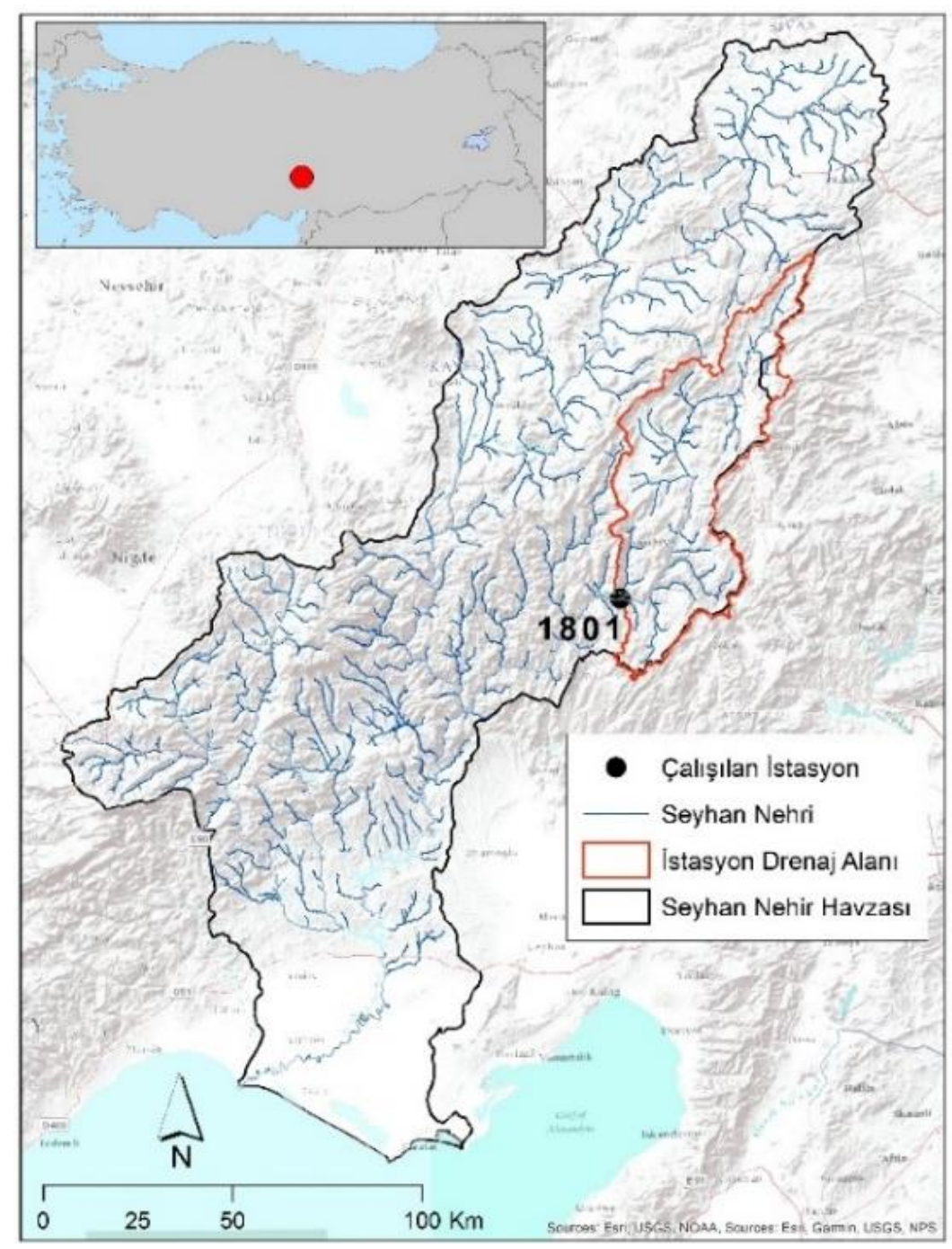

Şekil 1: Seyhan Havzası

Tablo 1: 1801 no'lu istasyona ait temel istatistikler

\begin{tabular}{ccccccccccc}
\hline İstasyon No & $\begin{array}{c}\text { Drenaj Alanı } \\
\left(\mathbf{k m}^{2}\right)\end{array}$ & Veri aralığı & $\begin{array}{c}\text { Minimum } \\
\left(\mathbf{m}^{\mathbf{3}} / \mathbf{s}\right)\end{array}$ & $\begin{array}{c}\text { Maksimum } \\
\left(\mathbf{m}^{3} / \mathbf{s}\right)\end{array}$ & $\begin{array}{c}\mathbf{X}_{\text {ort }} \\
\left(\mathbf{m}^{3} / \mathbf{s}\right)\end{array}$ & $\begin{array}{c}\mathbf{S}_{\mathbf{x}} \\
\left(\mathbf{m}^{3} / \mathbf{s}\right)\end{array}$ & $\begin{array}{c}\mathbf{X}_{\mathbf{m e d}} \\
\left(\mathbf{m}^{3} / \mathbf{s}\right)\end{array}$ & $\mathbf{C}_{\mathbf{v x}}$ & $\mathbf{C}_{\mathbf{s x}}$ & $\mathbf{k}_{\mathbf{x}}$ \\
\hline $\mathbf{1 8 0 1}$ & 2596.8 & $1935-2004$ & 5.2 & 433 & 29.84 & 26.04 & 19.2 & 0.87 & 3.14 & 17.12 \\
\hline
\end{tabular}




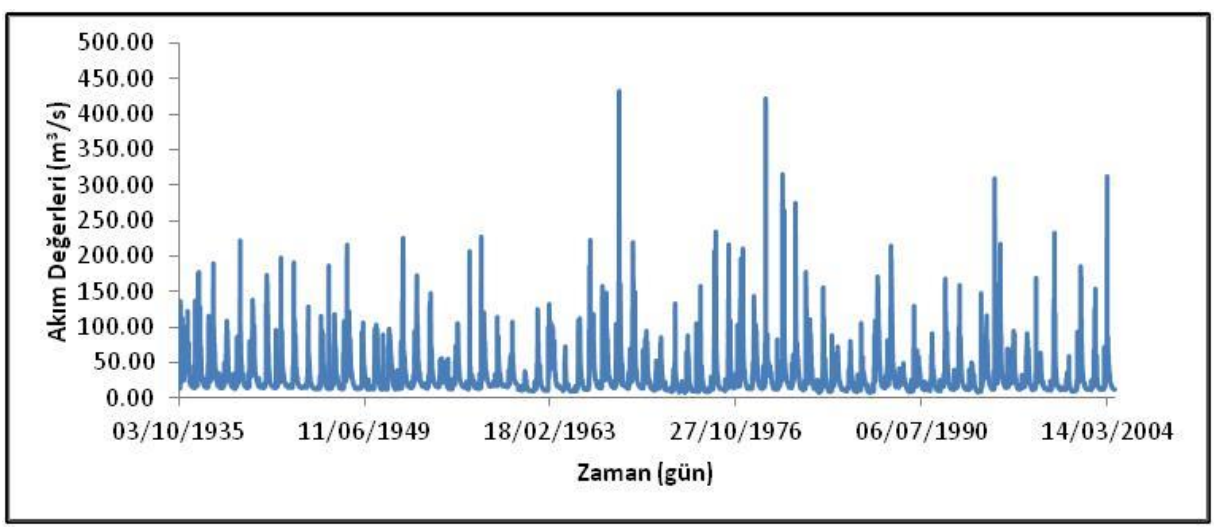

Şekil 2: Seyhan Havzası 1801 no’lu akım gözlem istasyonunda ölçülen günlük akımlar

\subsection{Eşik Üstü Pikler Yöntemi}

Akarsu akım serisinde $\mathrm{q}_{0}$ eşik değeri olarak belirlendiğinde bu eşik değerin üzerinde kalan akım değerleri eşik üstü pikler veya kısmi süreklilik serisi olarak adlandırılmaktadır (Şekil 3).

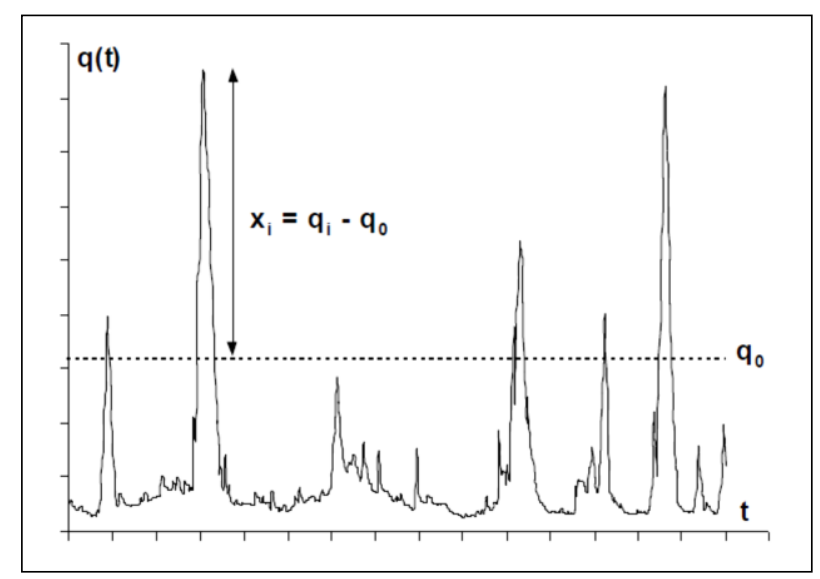

Şekil 3: Eşik üstü taşkınların belirlenmesi

İlgili yaklaşımda yıllık taşkın oluşumundan ziyade taşkın olayının genel olarak büyüklükler cinsinden kavramsal varlığı daha öne çıkarıldığından, oluşturulan seride bazı yıllarda birden fazla pik yer alırken, bazı yıllarda ise hiçbir gözlem analize esas nihai seride bulunmayabilir. Cunnane (1973) yıllık maksimum taşkınlara göre örnekleme varyansı daha küçük olan taşkın tahminlerinin elde edilebilmesi için yılda ortalama en az 1.65 pikin hesaba katılması gerekliliğini göstermiş; benzer şekilde eşik değerin yıllık ortalama pik sayısının 2-4 aralığında kalacak şekilde seçilmesinin uygun olacağı da farklı araştırmalarla ayrıca ortaya koyulmuştur (Bayazıt ve Önöz 2008).

Önceden de ifade edildiği üzere, eşik değerin küçük seçilmesi durumunda varyans azalacak fakat ardışı piklerin birbirinden bağımsız olması şartı sağlanamayacak; eşik değerin büyük seçilmesi durumunda da eşik değerin üzerinde sayıca az değerin kalması nedeniyle, varyans ortalama ve veri sayısına bağlı bir özellik olduğundan, varyansın artması söz konusu olacaktır. Bu sebeplerle eşik değerin belirlenmesi bu tür çalışmalarda oldukça önem arz etmektedir. qo değerini aşan pik $\left(\mathrm{q}_{\mathrm{i}}\right)$ ile $\mathrm{q}_{0}$ arasındaki fark $\left(\mathrm{x}_{\mathrm{i}}\right)$ başlıca değişken olarak düşünülmektedir. Aynı taşkın olayına ait birden fazla pik olması durumunda sadece gruptaki en büyük taşkın piki göz önüne alınır. Eşik üstü pikler arasındaki bağımsızlığı sağlayabilmek için pik oluşum zamanları arasındaki süre ve akım değerleri arasındaki farkların dikkate alınması gerekmektedir.

Eşik üstü pikler yöntemi ekstrem yağışların analizi ve kuraklık analizi gibi hidrolojik çalışmalarda da kullanılmakta ve ayrıca okyanus ve rüzgarla ilgili çalışmalarda da uygulama alanına sahip olmaktadır.

\subsection{Genelleştirilmiş Pareto Dağılımı}

Eşik üstü piklerin Poisson sürecine uygun olarak oluştuğu kabul edilmektedir (Lang vd. 1999, Cunnane 1979). Bu nedenle, eğer süreç yıllık bir periyodisiteye sahipse, t yıldaki aşılmaların sayısı n, Poisson dağılımına uymaktadır. 
$\mathrm{P}\{\mathrm{N}(\mathrm{t})=\mathrm{n}\}=\frac{(\lambda \mathrm{t})^{\mathrm{n}}}{\mathrm{n} !} \exp (-\lambda \mathrm{t}) \quad \mathrm{n}=0,1,2, \ldots$

Burada $\lambda$, yılda görülmesi beklenen eşik üstü pik sayısıdır. Shane ve Lynn (1964), Todorovic ve Zelenhasic (1970) tarafından yapılan eşik üstü pik değerlerinin modellenmesinin temelini oluşturan çalışmalarda eşik üstü piklerin bağımsız, özdeş dağılmış ve eksponansiyel dağılıma uygun olduğu kabulü yapılmıştır. Sunulan çalışmada, bu türden analizlerin yapıldığı çalışmalarda da tercih edilen GP dağılımı kullanılmıştır. GP dağılımı bir dağılım ailesi olup eklenik dağılım fonksiyonu aşağıdaki gibi verilmektedir.

$$
\left\{\begin{array}{l}
1-\exp \left(-\frac{x}{\alpha}\right), \kappa=0 \\
1-\left(1-\kappa \frac{x}{\alpha}\right)^{\frac{1}{\kappa}}, \kappa \neq 0
\end{array}\right.
$$

Burada $\alpha$ ve $\kappa$ sırasıyla dağılımın ölçek ve şekil parametreleri olmaktadır. $\kappa=0$ özel durumu, eksponansiyel dağılıma karşılık gelmektedir. GP dağılımının ortalaması ve varyansı ise Formül (3) ile hesaplanabilmektedir (Ribatet 2011).

$\mu=\mathrm{E}\{\mathrm{X}\}=\frac{\alpha}{1+\kappa}, \sigma^{2}=\operatorname{Var}\{\mathrm{X}\}=\frac{\alpha^{2}}{\left(1+\kappa^{2}\right)(1+2 \kappa)}$

\subsection{POT (Eşik Üstü Pikler) Paketi}

Ribatet ve Dutang (2019) eşik üstü pik serilerinin istatistiksel analizinin gerçekleştirilmesi amacıyla R (http://www.rproject.org) istatistiksel hesaplama ortamında çalışan bir program geliştirmiştir. POT (Eşik Üstü Pikler) paketi; eşik değerin belirlenmesi; dağılım parametrelerinin hesabı, model uygunluğunun sınanması ve parametreler ile kuantillerin (belirli bir tekerrür veya olasılığa karşılık gelen değer) güven aralıklarının belirlenmesi işlemlerini içermektedir.

\subsubsection{Eşik Değerin Belirlenmesi ve Bağımsızlık Kontrolü}

Eşik üstü pik serilerin frekans analizinde eşik değerin belirlenmesi aşaması analiz sonuçlarını etkileyecek derecede öneme sahiptir. Sunulan çalışmada eşik değerin optimum değerinin belirlenebilmesi; eşik değer seçme grafiği, ortalama kalıntı ömrü grafiği, yayılım indeksi grafiği ile ortalama ve standart sapmaya bağlı yöntem olmak üzere dört farklı yöntemle gerçekleştirilmiştir. POT içeriğinde yer alan L-momentler grafiği yöntemi, paketi geliştiren araştırmacılar tarafından gerçek veriler üzerinde uygulandığında performansının zayıf olması sebebiyle önerilmediğinden çalışmada uygulanmamıştır (Ribatet 2011).

Parametre tahminleri grafiğinde, hesaplanan şekil ve değiştirilmiş ölçek parametrelerinin eşik değerlere göre gidiş grafiği çizilerek parametrelerin yaklaşık sabit olduğu eşik değer optimum değer olarak belirlenmektedir. X değişkeni $\mu_{0}, \alpha_{0}, \kappa_{0}$ parametreli bir dağılıma sahip olduğu düşünüldüğünde, $\mu_{1}>\mu_{0}$ olmak üzere $\mu_{1}$ farklı bir eşik değer olarak alındığında $X \mid X>\mu_{1}$ rastgele değişkeni de GP dağılımlı olmakta ve parametreleri $\alpha_{1}=\alpha_{0}+\kappa_{0}\left(\mu_{1}-\mu_{0}\right)$ ve $\kappa_{1}=\kappa_{0}$ olmaktadır. Yeni parametre değeri ise aşağıdaki gibi verilmektedir.

$\alpha_{*}=\alpha_{1}-\kappa_{1} \mu_{1}$

Burada $\alpha_{*}, \mu_{1}$ 'den bağımsızdır. Bu nedenle $\alpha_{*}$ ve $\kappa_{1}$ tahminleri $\mu_{0}$ uygun bir eşik değer olarak belirlendiğinde $\mu_{1}>\mu_{0}$ için sabit olmaktadır. Eşik değer belirlemede kullanılan grafikte aşağıdaki noktalamalar gösterilmektedir.

$\left\{\left(\mu_{1}, \alpha_{*}\right): \mu_{1} \leq \mathrm{x}_{\max }\right\}$ ve

$\left\{\left(\mu_{1}, \kappa_{1}\right): \mu_{1} \leq x_{\max }\right\}$

Burada $x_{\max }$, gözlemlerin en büyük değerli olanıdır. Ortalama kalıntı ömrü grafiği, eşik değere karşılık aşılmaların ortalamasını gösteren bir grafik olmaktadır. Bu grafikte, GP dağılımlı eşik değerin üzerindeki aşılmalar $-\kappa /(\kappa+1)$ eğimine sahip düz bir çizgi göstermelidir. Yayılım indeksi grafiği Formül (6) ile verilen yayılım indeksinin (DI) eşik değerlere göre değişiminini gösteren grafiktir.

$\mathrm{DI}=\frac{\mathrm{s}^{2}}{\lambda}$

Ekstrem değer teorisine göre eşik değeri aşan değerlerin dağılımı GP dağılımı gösterebilmektedir. Yine aynı teoriye göre bu aşılmaların görülme sayısı Poisson sürecine uymalıdır. 
Poisson dağılımlı rastgele bir değişken için varyansın ortalamaya oranı (yayılım indeksi) 1'e eşittir. Yayılım indeksinin güven aralığı $\chi^{2}$ testi ile ifade edilebilir. Tahmin edilen yayılım indeksi aşağıda verilen aralıkta kaldığında Poisson hipotezi kabul edilmektedir.

$\left[\frac{\chi_{\alpha / 2, \mathrm{M}-1}^{2}}{\mathrm{M}-1}, \frac{\chi_{1-\alpha / 2, \mathrm{M}-1}^{2}}{\mathrm{M}-1}\right]$

Burada M örnekteki toplam sene sayısını göstermektedir (Ribatet 2011). Yukarıda verilen ve POT paketinin içerisinde yer alan eşik değer belirleme yöntemlerinden başka, sunulan çalışmada Rosbjerg ve Madsen (1992) tarafından önerilen ve Formül (8) ile hesaplanan eşik değer belirleme yöntemi de uygulanmıştır.

$\mathrm{q}_{0}=\mathrm{E}\{\mathrm{Q}\}+\mathrm{kS}\{\mathrm{Q}\}$

Burada $\mathrm{q}_{0}$ eşik değeri, $\mathrm{E}\{\mathrm{Q}\}$ ve $\mathrm{S}\{\mathrm{Q}\}$ ise sırasıyla ortalama ve standart sapmayı göstermektedir. $\mathrm{k}$ ise değeri 3-3.5 arasında değișen frekans faktörüdür.

Çalışmada, eşik değer üzerinde kalan serinin bağımsızlık koşulunu sağlayıp sağlamadığına dair kontrolü sağlamak amacıyla otokorelasyon analizi yapılmıştır. Rastgele bir sürecin otokorelasyonu, farklı mesafelerdeki değerler arasındaki korelasyonun ölçüsü olarak tanımlanmaktadır. Otokorelasyon katsayısı, verileri üreten olasılık modeline dair bir içgörü sağlamaktadır. Otokorelasyon, bir serisel bağımlılık türü olup, bir zaman serisinin kendisinin gecikmeli bir versiyonuyla doğrusal olarak ilişkili olduğunun göstergesidir. Otokorelasyon katsayısı Formül (9) ile verilmektedir.

$r_{k}=\frac{c_{k}}{c_{0}}$

Burada $c_{0}$, serinin varyansını; $c_{k}$, k. lag (öteleme) için otokovaryans fonksiyonu olup Formül (10)’da verilmiştir.

$c_{k}=\frac{1}{n} \sum_{i=1}^{n-k}\left(y_{i}-\bar{y}\right)\left(y_{i+k}-\bar{y}\right)=\frac{1}{n} \sum_{i=k+1}^{n}\left(y_{i}-\bar{y}\right)\left(y_{i-k}-\bar{y}\right) \quad k \geq 0 i c ̧ i n$

$\bar{y}$, serinin ortalamasını göstermektedir. -1 ila +1 arasında değişen otokorelasyon katsayısının farklı ötelemeler için elde edilen değerleri korelogram ile gösterilmektedir (Madsen 2007).

\subsubsection{Dağılım Parametrelerinin Hesaplanması}

Çalışmada GP dağılımın parametreleri POT paketinde yer alan yöntemler içerisinde yer alan; Maksimum Olabilirlik (MLE), Olasılık Ağırlıklı Momentler (L-momentler) ve Momentler (MOM) yöntemleri göz önüne alınarak üç farklı şekilde hesaplanmıştır.

\subsubsection{Model Uygunluğunun Sınanması}

Genelleştirilmiş Pareto Dağılımında model uygunluğunun sınanması olasılık-olasılık, kuantil-kuantil, yoğunluk ve tekerrür-kuantil grafikleri ile gerçekleştirilmektedir. Sunulan çalışmada bunlara ek olarak Ki-Kare ve Anderson Darling testleri de uygulanarak dağılım uygunluğu sınanmıştır.

Olasılık-Olasılık grafiği, GP dağılımı ile elde edilen teorik olasılıklar ile gözlenmiş değerlerin Hosking ve Wallis (1987) tarafından önerilen ve Formül (11) ile hesaplanan ampirik olasılıklar arasındaki ilişkiyi gösteren grafiktir. Noktalamaların $\mathrm{y}=\mathrm{x}$ doğrusuna yakın olması seçilen dağılımın uygunluğunu ifade etmektedir.

$p_{\mathrm{j}: \mathrm{n}}=\frac{\mathrm{j}-0.35}{\mathrm{n}}$

Burada n toplam gözlem sayısını ifade etmektedir. Kuantil-Kuantil grafiği teorik ve gözlenmiş kuantil değerleri arasındaki ilişkiyi ifade etmektedir. Olasılık-Olasılık grafiğinde olduğu gibi noktalamaların $\mathrm{y}=\mathrm{x}$ doğrusuna yakın olması seçilen dağılımın uygunluğunu göstermektedir.

Yoğunluk grafiği, teorik yoğunluk ve olasılık yoğunluk fonksiyonu tahminini parametrik olmayan yöntemle gerçekleştiren kernel olasılık tahmini ilişkisini gösteren grafiktir. Bu iki değer birbirine benzer olduğunda uygulanan dağılımın uygun olduğu sonucuna ulaşılmaktadır.

Tekerrür-Kuantil grafiği ise tekerrür aralığına karşılık gelen teorik kuantillerin noktalanmasıyla elde edilir. Gözlenmiş değerler ile teorik değerler birbirine yakın olduğunda seçilen modelin uygun olduğu kabul edilmektedir (Ribatet ve Dutang 2019). 


\subsubsection{Gumbel Dağılımı ve L-Momentler}

Gumbel dağılımın parametreleri, $\xi$ (yer) ve $\alpha$ (ölçek) olmak üzere 2 tanedir. $\mathrm{x}$ değişkeni $-\infty<\mathrm{x}<\infty$ aralığında olmak üzere dağılımın olasılık yoğunluk fonksiyonu ve eklenik dağılım fonksiyonu Formül (12) ve (13) ile verilmektedir (Hosking ve Wallis 1997).

$$
\begin{aligned}
& f(x)=\alpha^{-1} \exp \left\{-\frac{(x-\xi)}{\alpha}\right\} \exp \left[-\exp \left\{-\frac{(x-\xi)}{\alpha}\right\}\right] \\
& F(x)=\exp \left[-\exp \left\{-\frac{(x-\xi)}{\alpha}\right\}\right]
\end{aligned}
$$

L-moment değerleri $\gamma$ Euler sabiti (0.5772) olmak üzere Formül (14)-(17)'de, dağılımın parametre değerleri de Formül (18)'deki gibidir (Hosking ve Wallis 1997).

$$
\begin{aligned}
& \lambda_{1}=\xi+\alpha \gamma \\
& \lambda_{2}=\alpha \log 2 \\
& \tau_{3}=0.1699=\log \left(\frac{9}{8}\right) / \log 2 \\
& \tau_{3}=0.1504=(16 \log 2-10 \log 3) / \log 2 \\
& \alpha=\frac{\lambda_{2}}{\log 2}, \quad \xi=\lambda_{1}-\gamma \alpha
\end{aligned}
$$

\section{Bulgular ve Tartışma}

Eşik üstü pik serilerinde karşılaşılan iki problemden biri taşkın piklerinin bağımsız bir zaman serisi olamayabileceği, diğeri ise eşik değerin belirlenmesidir. Amerika Birleşik Devletleri Su Kaynakları Konseyi (Water Resources Council, USWRC) tarafından taşkın piklerinin bağımsız olarak kabul edilmesi için: (1) olaylar arasında geçen zamanın 5+ $\ln$ (Drenaj Alanı) ile drenaj alanın mil ${ }^{2}$ olarak alınıp gün biriminde hesaplanan bu değerden büyük olması, (2) ardarda yaşanan iki taşkın olayında akım değerindeki farkın incelenen iki taşkın pikinden küçük olanın değerinin \%75'inin altında olması gerektiği belirtilmiştir (USWRC 1982).

Sunulan çalışmada 1801 no'lu akım gözlem istasyonunun drenaj alanı mil ${ }^{2}$ cinsinden alınıp yukarıda verilen eşitlik kullanıldığında taşkın piklerinin bağımsız olmaları için gereken minimum süre 12 gün olarak hesaplanmış, hesaplamalarda bu süre 14 gün olarak alınmıştır.

Eşik üstü pik serileri yıllık maksimum seriler ile karşılaştırıldığında daha fazla problemi çözme gerekliliği ortaya çıkabilmektedir. Zaman serileri içsel bağımlı olduğunda eşik değerin üzerinde kalan taşkın değerlerinin bağımlı olması ihtimali ortaya çıkmaktadır. POT paketinde yer alan gruplama fonksiyonu eşik değer üzerindeki piklerin belirlenmesini bağımsızlık koşulunun sağlanması ile gerçekleştirmeye çalışmaktadır. Gruplama fonksiyonunun hesabı için eşik değer tahminine ve bağımsızlık koşulunun sağlanabileceği zaman (gün) değerine ihtiyaç duyulmaktadır.

\subsection{Eşik Değerin Belirlenmesi ve Bağımsızlık Kontrolü}

Eşik değerin belirlenmesi için kullanılan üç grafik yöntem üzerinden farklı değerler denenerek işlemler gerçekleştirilmiş ve eşik değerin $76 \mathrm{~m}^{3} / \mathrm{s}$ olarak alınabileceği belirlenmiştir. Grafik yöntemlerle elde edilen sonuçlar sırasıyla Şekil 46'da sunulmuştur.

Parametrelerin yaklaşık sabit olduğu eşik değer optimum değer olarak alınacağından Şekil 4'te verilen parametre tahminleri grafiğinin 76-150 aralığında yaklaşık sabit doğrusal kaldığı görülmektedir.

Şekil 5'te verilen ortalama kalıntı ömrü grafiğine göre 76 m³/s değerinin makul olduğu ve $76-95$ aralığında yaklaşık sabit doğrusal olduğu; Şekil 6'daki yayılım indeksi grafiğine göre $76 \mathrm{~m}^{3} / \mathrm{s}$ için güven sınırları içerisinde kalındığından tahminin kabul edilebilir olduğu söylenebilmektedir. Yayılım indeksi bire yaklaştıkça eşik değeri artmaktadır. Ancak incelenen durumda, yayılım indeksinin değerinin göreceli olarak düşük bir eşik değer için zaten 1'e çok yakın olduğunu gözlemlemek mümkündür. Yöntemde eşik değerin belirlenmesi için yılda ortalama taşkın sayısının en az 1.65 olacağ göz önüne alınarak denemeler yapılmıştır.

Rosbjerg ve Madsen (1992) yöntemi uygulandı̆̆ında ise eşik değerin, k frekans faktörünün sınırlarına göre 107-120 $\mathrm{m}^{3} / \mathrm{s}$ arasında olabileceği hesaplanmış fakat yılda ortalama taşkın sayısı $76 \mathrm{~m}^{3} / \mathrm{s}$ için $2.14,120 \mathrm{~m}^{3} / \mathrm{s}$ değeri alındığında $0.93,95 \mathrm{~m}^{3} / \mathrm{s}$ alındığında ise 1.54 olarak hesaplandığından eşik değer için $76 \mathrm{~m}^{3} / \mathrm{s}$ değerinin alınmasının literatürde belirtilen ve en az 1.65 olması beklenen yılda ortalama taşkın sayısı açısından daha uygun olacağı sonucuna varılmıştır. 
Yapılan diğer araştırmalarda incelendiğinde, eşik seçimi için genel geçer bir yöntem bulunmadığını söylemek mümkündür (Cunnane 1979; Bezak vd. 2014). Bununla birlikte Lang vd. (1999) eşik seçiminin sürecin dağılımının seçimi, eşik üstü dağılımı ve bağımsızlık hipotezi ile sıkı bir şekilde bağlantılı olduğunu ortaya koymuşlar; eşik seçimi işleminin seçilen modeli doğrulamaya katkıda bulunan tüm bu farklı unsurların analizi olarak nitelemişlerdir.
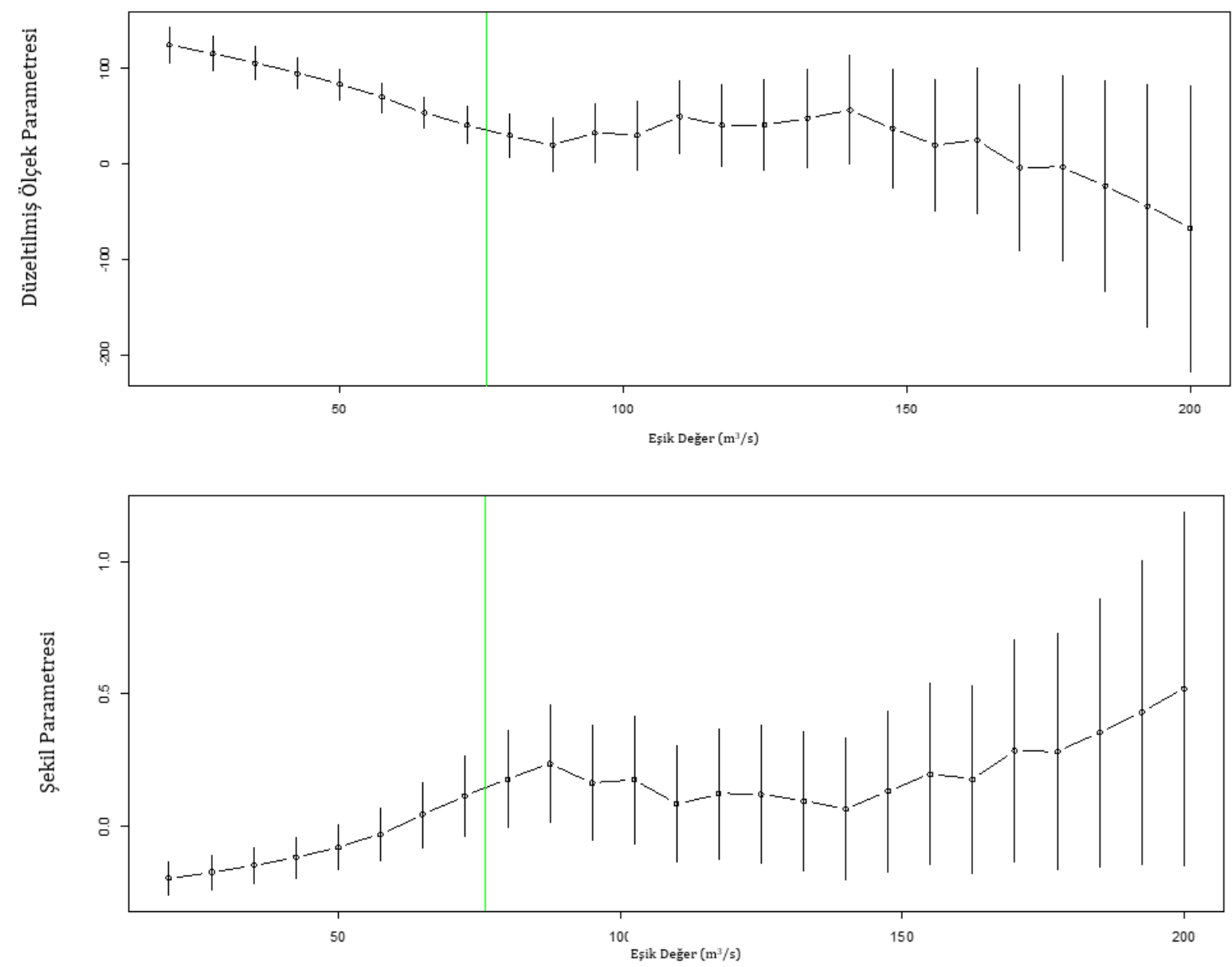

Şekil 4: Parametre tahminleri grafikleri

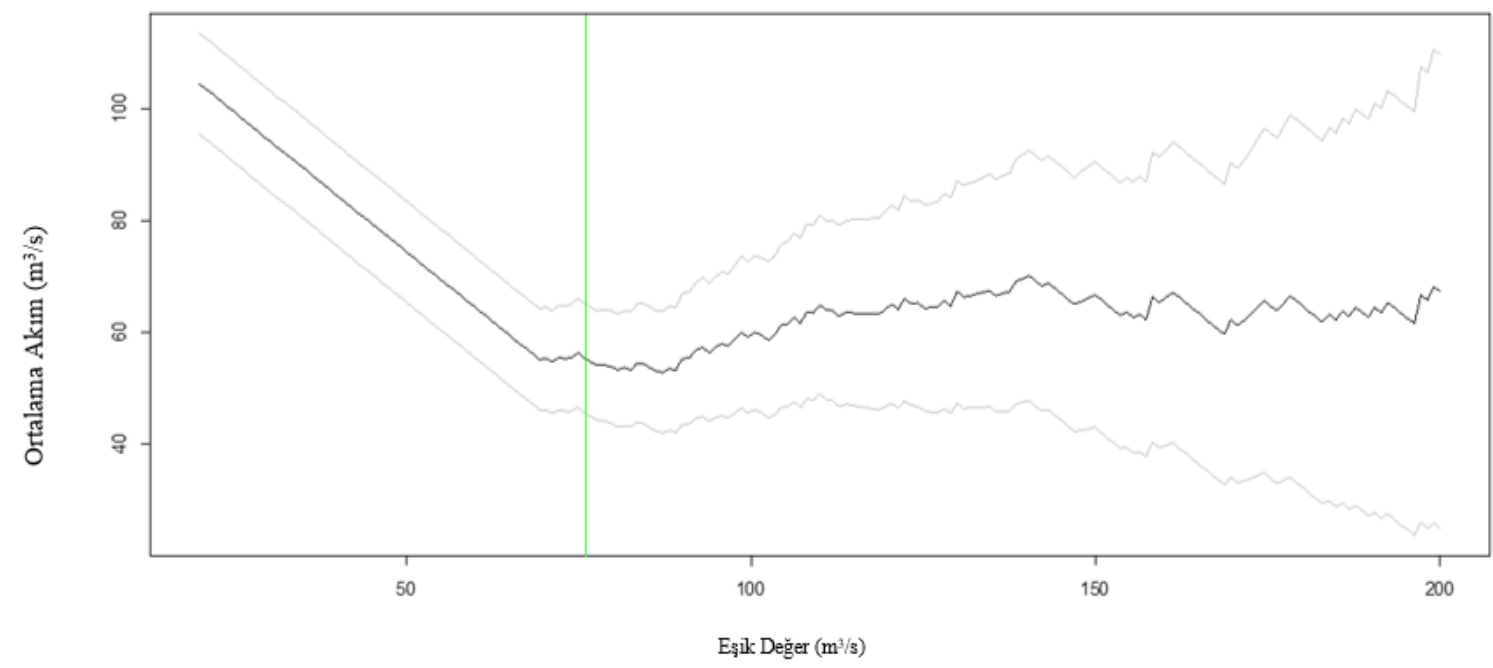

Şekil 5: Ortalama kalıntı ömrü grafiği 


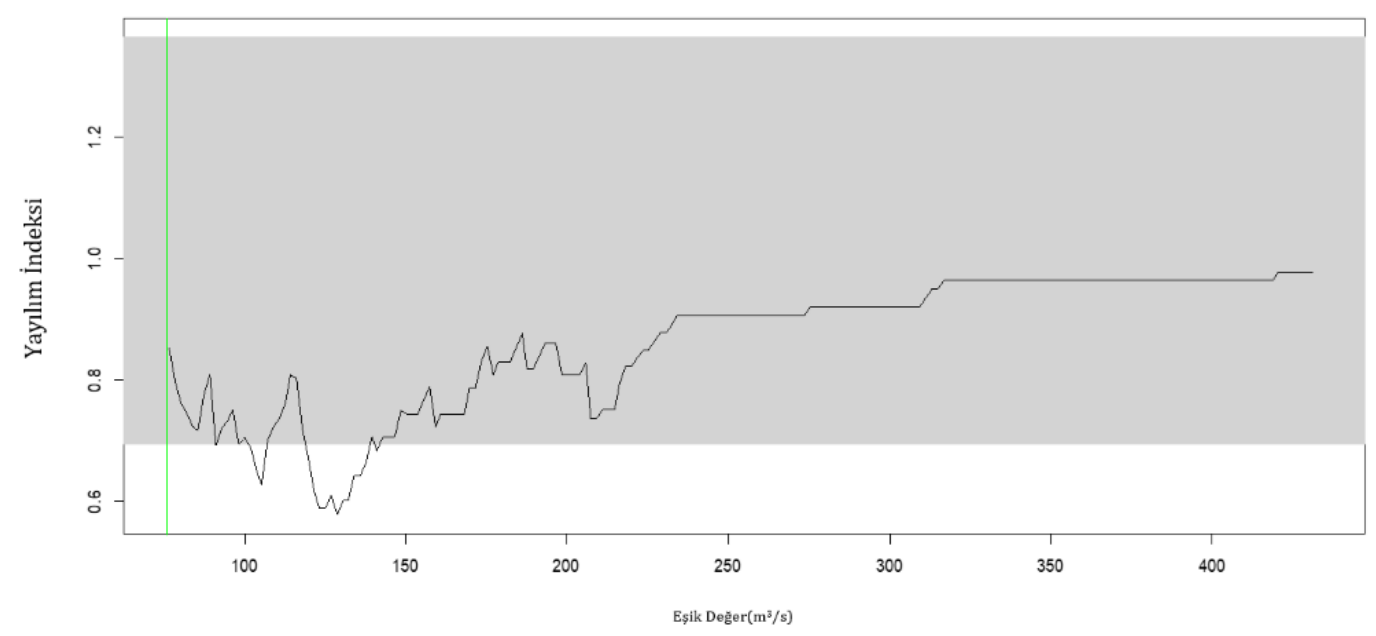

Şekil 6: Yayılım indeksi grafiği

Şekil 7, eşik değer üzerinde kalan ve hesaplamalarda kullanılan taşkın değerlerini göstermektedir. Elde edilen bu değerlerin bağımsızlık koşulunu sağlayıp sağlamadığını kontrol etmek amacıyla seriye otokorelasyon testi uygulanmış ve korelogramı elde edilmiştir (Şekil 8).

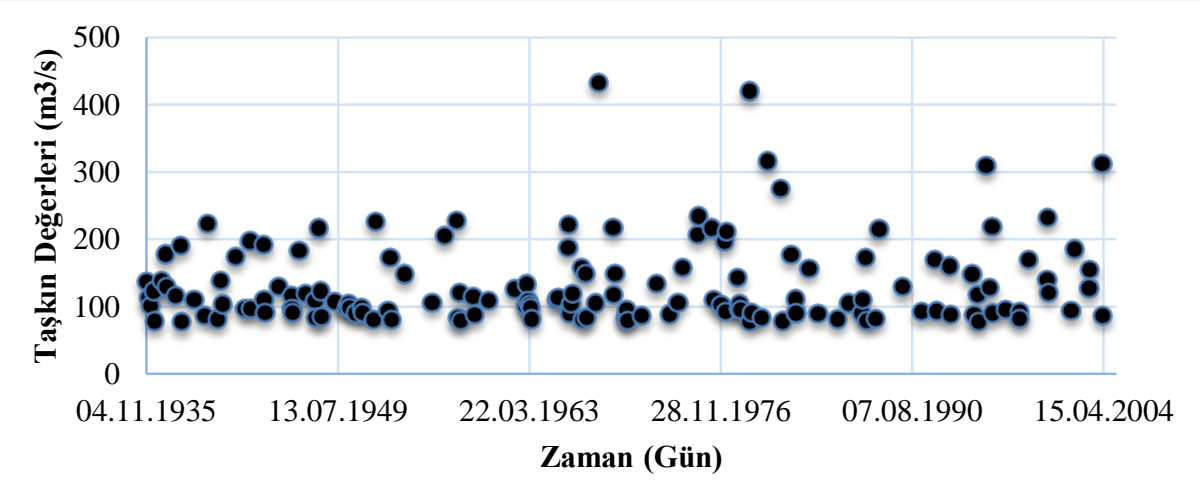

Şekil 7: Eşik değer üzerinde kalan taşkın değerleri

Seyhan_1801

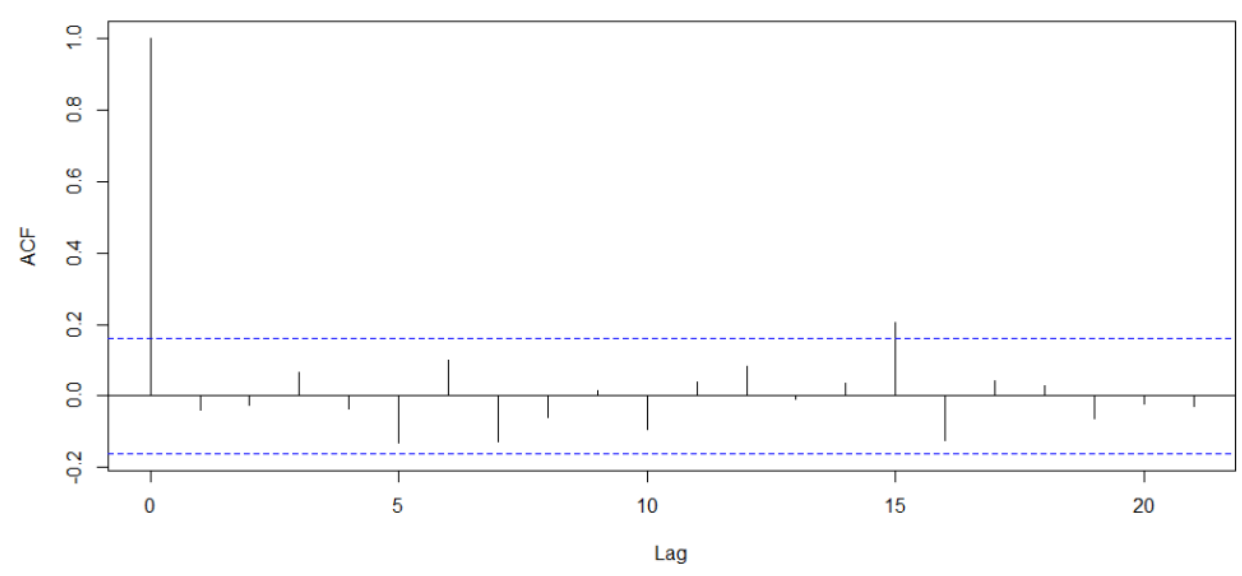

Şekil 8: Eşik üstü pik değerlere ait korelogram

Farklı ötelemeler için Formül (9)'un uygulanmasıyla elde edilen korelasyon katsayılarını ve güven sınırını gösteren Şekil (8)'e göre eşik üstü piklerin bağımsız olduğu tespit edilmiştir. $\mathrm{r}_{0}=\mathrm{c}_{0} / \mathrm{c}_{0}$ olacağından 1 'e eşittir. 
İçsel bağımlılık özellikle k=1 için hesaplanan otokorelasyon katsayısının güven sınırlarının dışında olduğu durumlar için ifade edileceğinden incelenen seride içsel bağımlılık bulunmadığını söylemek mümkündür. k=15 için hesaplanan otokorelasyon katsayısının sınırlar dışında kalmış olması rastgele karşılaşılmış bir olay olarak nitelendirilebilir.

\subsection{GP Dağılımının Parametrelerinin Hesabı ve Model Uygunluğunun Sınanması}

GP dağılımının ölçek ve şekil parametrelerinin uygulanan parametre tahmin yöntemlerine göre elde edilen sonuçları Tablo 2'de sunulmuştur.

Tablo 2: GP dağılımının uygulanan parametre tahmin yöntemlerine göre hesaplanan parametre tahminleri

\begin{tabular}{|l|c|c|}
\hline \multicolumn{1}{|c|}{ Yöntem } & Şekil Parametresi & Ölçek Parametresi \\
\hline Maksimum Olabilirlik & 0.102 & 51.070 \\
\hline Olasılık Ağırlıklı Momentler (L-momentler) & 0.125 & 49.737 \\
\hline Momentler & 0.085 & 51.993 \\
\hline
\end{tabular}

Çalışmanın sonraki aşamasında, momentler yöntemi göz önüne alınmayıp, maksimum olabilirlik ve L-momentler yöntemlerine göre dağılımın gözlenmiş değerlere uygunluğunun sınanması işlemi gerçekleştirilmiştir. Bunun için elde edilen Olasılık-Olasılık, Kuantil-Kuantil, Yoğunluk-Kuantil ve Tekerrür Aralığ1-Kuantil grafikleri maksimum olabilirlik tahminlerine göre Şekil 8'de, L-momentler tahminlerine göre ise Şekil 9'da verilmiştir. Bu grafiklere göre GP dağılımının gözlenmiş verilere uygun olduğu sonucuna varılmaktadır.
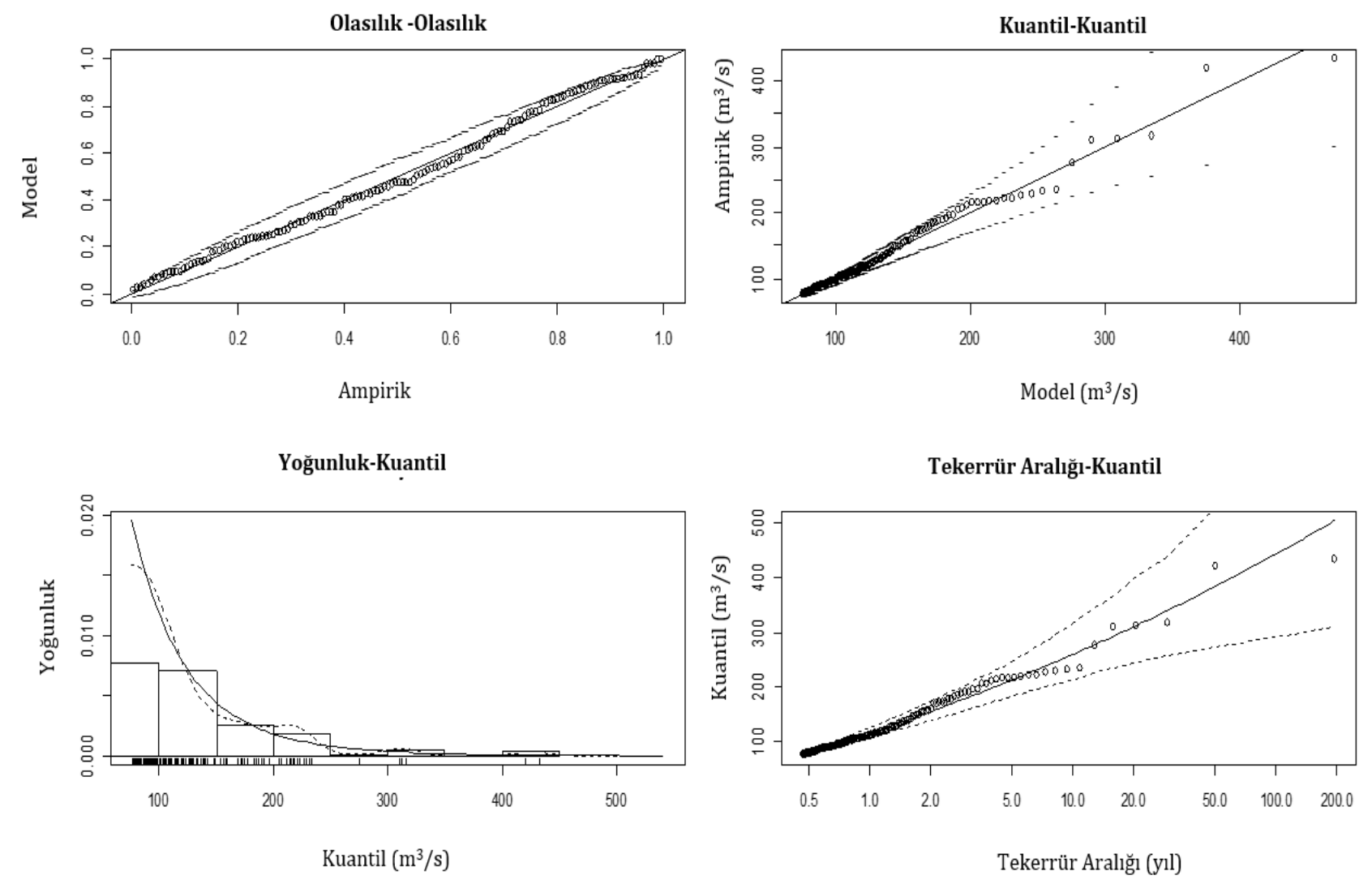

Şekil 8: Dağılım uygunluğunun maksimum olabilirlik yöntemi tahminleri ile sınanması 


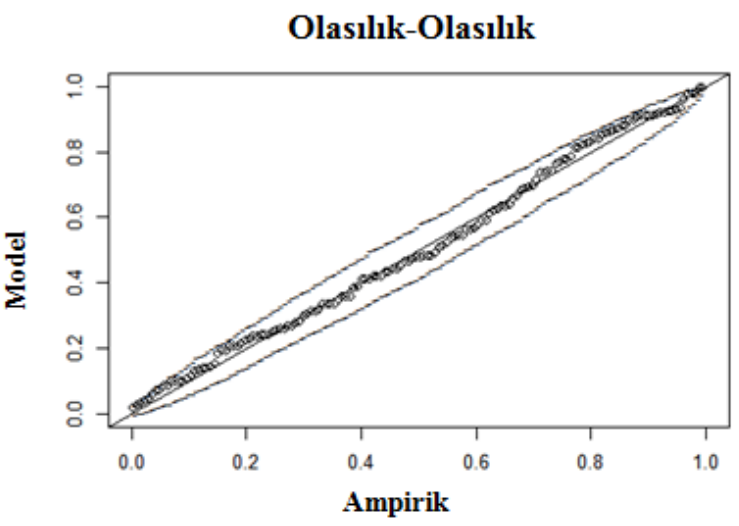

Yoğunluk-Kuantil

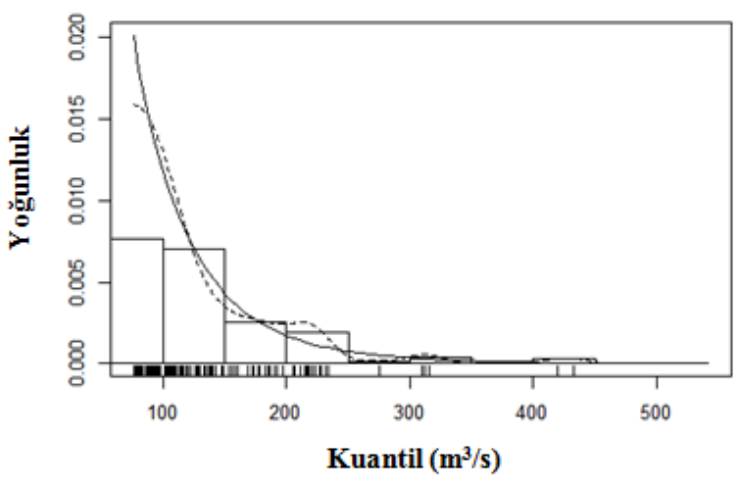

Kuantil-Kuantil

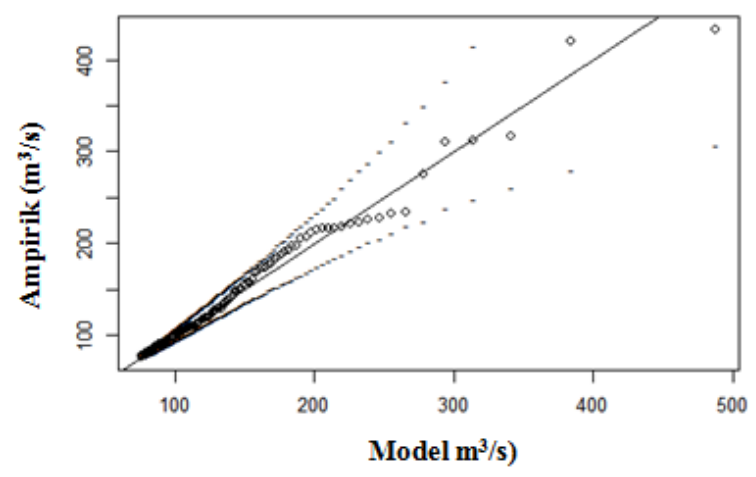

Tekerrür Aralığı-Kuantil

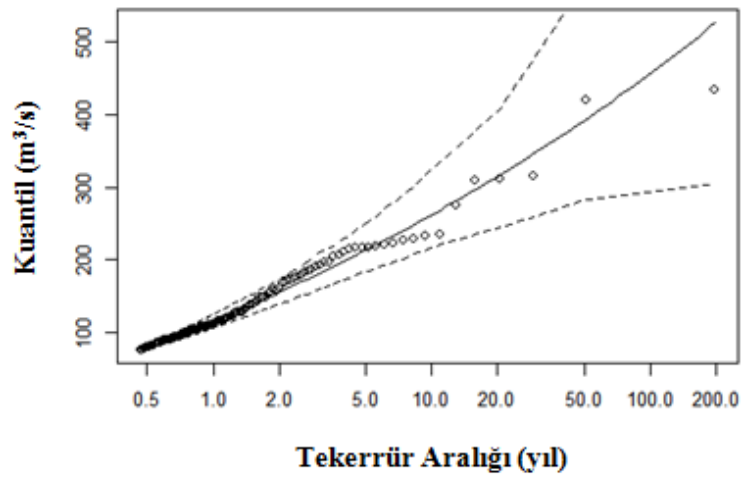

Şekil 9: Dağılım uygunluğunun L-momentler yöntemi tahminleri ile sınanması

Dağılım uygunluğunun sınanması Anderson Darling ve Ki-Kare testleri uygulanarak da gerçekleştirilmiş ve GP dağılımı, incelenen 65 dağılım içerisinden en iyi üçüncü dağılım olarak belirlenmiştir (Tablo 3).

Tablo 3: Anderson Darling ve Ki-Kare testleri sonuçlarına göre en uygun dağılım sıralaması

\begin{tabular}{|l|l|l|l|l|}
\hline & \multicolumn{2}{|c|}{ Anderson Darling } & \multicolumn{2}{c|}{ Ki-Kare } \\
\hline & İstatistik Değeri & Sıra No & İstatistik Değeri & Sıra No \\
\hline Fatigue Life (3P) & 0.28825 & 1 & 1.8528 & 1 \\
\hline Pearson 6 (4P) & 0.32934 & 2 & 2.4236 & 2 \\
\hline Genelleştirilmiş Pareto & 0.44573 & 3 & 2.4236 & 3 \\
\hline
\end{tabular}

\subsection{Belirsizlik Analizi}

Taşkın frekans analizinde, gözlenmiş taşkın serilerine belirlenen en uygun dağılım uygulandıktan sonraki adım belirsizlik analizinin gerçekleştirilmesidir. Taşkın frekans analizinde belirsizlik analizinin yapılmasının nedenlerinden ilki, gözlenmiş taşkınların nispeten küçük örnek olmaları, ikincisi ise bu gözlemlere uygunluğu sınanan olasılık dağılımları ile ilgili kabuller yapmak zorunluluğudur. Bu nedenle, taşkın frekans analizindeki belirsizlikler kaçınılmaz olmaktadır. Taşkın frekans analizi sonuçlarındaki belirsizliğin ifadesi için kullanılan alışılagelmiş yöntem, elde edilen sonuçlar için güven aralığı oluşturulmasıdır. Parametre ve kuantil tahminlerinin güven aralıkları asimptotik teori, Fisher'in gözlenen bilgi matrisi ve Delta yöntemine dayanarak POT paketi ile elde edilmiştir.

Sunulan çalışmada Seyhan Havzası 1801 no'lu istasyonun taşkın frekans analizi sonucunda maksimum olabilirlik ve L-momentler yöntemine göre elde edilen parametre değerlerine ait güven sınırları ile kuantil tahminlerinin güven sınırları \%95 güven düzeyi için oluşturulmuştur (Tablo 4 ve Tablo 5). Bulunan bu değerler, hesaplanan şekil ve ölçek parametrelerinin sınırlar içerisinde kaldığını, dolayısıyla hesaplanan değerlerin uygunluğunu göstermektedir. Tablo 6'da kullanılan parametre yöntemine göre yapılan tahminlerde de tekerrür aralığ1 arttıkça tahminler arasındaki farkın arttığ görülmektedir. 
Tablo 4: GP dağılımının parametrelerinin güven sınırları

\begin{tabular}{|c|c|c|c|}
\hline $\begin{array}{c}\text { Parametre Tahmin } \\
\text { Yöntemi }\end{array}$ & $\begin{array}{c}\text { Parametrelerin Güven } \\
\text { Aralı̆̆ }\end{array}$ & Şekil Parametresi & Ölçek Parametresi \\
\hline Maksimum & Alt Sınır & -0.089 & 38.332 \\
\cline { 2 - 4 } Olabilirlik Yöntemi & Üst Sınır & 0.293 & 63.809 \\
\hline L-Momentler & Alt Sınır & -0.063 & 37.364 \\
\cline { 2 - 4 } Yöntemi & Üst Sınır & 0.312 & 62.110 \\
\hline
\end{tabular}

Tablo 5: Farklı tekerrürlere karşılık gelen kuantil tahminleri ve güven sınırları

\begin{tabular}{|c|c|c|c|c|}
\hline $\begin{array}{c}\text { Parametre } \\
\text { Tahmin Yöntemi }\end{array}$ & $\begin{array}{c}\text { Tekerrür Süresi } \\
\text { (YıI) }\end{array}$ & Kuantil $\left(\mathbf{m}^{3} / \mathbf{s}\right)$ & $\begin{array}{c}\text { Kuantil Alt Sinırı } \\
\left(\mathbf{m}^{3} / \mathbf{s}\right)\end{array}$ & $\begin{array}{c}\text { Kuantil Üst Sinırı } \\
\left(\mathbf{m}^{3} / \mathbf{s}\right)\end{array}$ \\
\hline \multirow{9}{*}{$\begin{array}{c}\text { Maksimum } \\
\text { Olabilirlik } \\
\text { Yöntemi }\end{array}$} & 2 & 156 & 142 & 171 \\
\hline & 5 & 213 & 187 & 239 \\
\hline & 10 & 260 & 219 & 300 \\
\hline & 20 & 310 & 246 & 374 \\
\hline & 50 & 382 & 274 & 490 \\
\hline & 100 & 441 & 287 & 596 \\
\hline & 200 & 504 & 292 & 717 \\
\hline & 500 & 595 & 285 & 905 \\
\hline & 1000 & 671 & 269 & 1072 \\
\hline \multirow{9}{*}{$\begin{array}{c}\text { L-Momentler } \\
\text { Yöntemi }\end{array}$} & 2 & 155 & 140 & 170 \\
\hline & 5 & 213 & 187 & 240 \\
\hline & 10 & 262 & 220 & 304 \\
\hline & 20 & 314 & 249 & 380 \\
\hline & 50 & 392 & 279 & 505 \\
\hline & 100 & 456 & 293 & 619 \\
\hline & 200 & 526 & 300 & 752 \\
\hline & 500 & 629 & 295 & 963 \\
\hline & 1000 & 715 & 278 & 1152 \\
\hline
\end{tabular}

\subsection{Eşik Üstü Pikler ve Yıllık Maksimum Serilerden Elde Edilen Taşkın Tahminlerinin Karşılaştırılması}

Yıllık maksimum değerler kullanılarak gerçekleştirilen taşkın frekans analizi sonucunda Gumbel Dağılımı en uygun dağılım olarak belirlenmiş ve L-momentler yöntemine göre dağılım parametreleri $\alpha=89.1$ ve u=144.6 olarak hesaplanmıştır.

Çalışmanın son aşamasında her ikisinin de parametreleri L-momentler ile hesaplanan yıllık maksimum değerler kullanılarak gerçekleştirilen taşkın frekans analizi sonuçları ile eşik üstü pikler yöntemine göre yapılan analiz sonuçları karşılaştırmalı olarak Tablo 6'da sunulmuştur.

Tablo 6: Eşik üstü pikler ve yıllık maksimum serilerden elde edilen taşkın tahminleri

\begin{tabular}{|c|c|c|}
\hline $\begin{array}{c}\text { Tekerrür Süresi } \\
\text { (Yıl) }\end{array}$ & $\begin{array}{c}\text { Eşik Üstü Pikler Yöntemine } \\
\text { Göre Elde Edilen Tahmini } \\
\text { Taşkın Değerleri }\left(\mathbf{m}^{\mathbf{3}} / \mathbf{s}\right)\end{array}$ & $\begin{array}{c}\text { Yıllık Maksimum Değerlere Göre } \\
\text { Elde Edilen Tahmini Taşkın } \\
\text { Değerleri }\left(\mathbf{m}^{\mathbf{3}} / \mathbf{s}\right)\end{array}$ \\
\hline 2 & 155 & 175 \\
\hline 5 & 213 & 268 \\
\hline 10 & 260 & 329 \\
\hline 20 & 310 & 388 \\
\hline 50 & 382 & 464 \\
\hline 100 & 441 & 521 \\
\hline 200 & 526 & 585 \\
\hline 500 & 629 & 665 \\
\hline 1000 & 715 & 723 \\
\hline
\end{tabular}

Yukarıda verilen tabloya göre yıllık maksimumlardan oluşan seri kullanılarak elde edilen taşkın tahminlerinin eşik üstü piklerin oluşturduğu seri kullanılarak elde edilen tahminlerden tekerrür aralığına göre farklılaştığı görülmektedir. Tahminler arasındaki fark tekerrür aralığı arttıkça azalmaktadır. 


\section{Sonuçlar}

Sunulan çalışmada Seyhan Havzası'nda yer alan 1801 no'lu istasyon için eşik üstü pik değerleri kullanılarak taşkın frekans analizi gerçekleştirilmiştir. Eşik değerin belirlenmesi; eşik değer seçme grafiği, ortalama kalıntı ömrü grafiğgi, yayılım indeksi grafiği ile Rosbjerg ve Madsen yöntemi olmak üzere dört farklı yöntemle belirlenmiştir. Taşkın piklerinin bağımsız olma koşulunun sağlanabilmesi için taşkın olayları arasındaki sürenin 14 gün olarak alınması uygun bulunmuş ve eşik değer hem grafik yöntemler hem de Rosbjerg ve Madsen yöntemine dayanarak $76 \mathrm{~m}^{3} / \mathrm{s}$ olarak belirlenmiştir. Ayrıca eşik üstü pik serisine bağımsızlık testi uygulanmış ve serinin bağımsız olduğu ortaya konmuştur. Oluşturulan eşik üstü pik serisine kısmi süreklilik serilerinde sıklıkla kullanılan Genelleştirilmiş Pareto dağılımı uygulanmış dağılımın şekil ve ölçek parametreleri maksimum olabilirlik, L-momentler ve momentler yöntemi olmak üzere üç farklı yolla hesaplanmıştır. Dağılımın gözlenmiş değerlere uygunluğu hem grafikler hem de Ki-Kare ve Anderson Darling testleri ile sınanmış ve uygulanan modelin uygunluğu ortaya konulmuştur. 2, 5, 10, 25, 50, 100, 200, 500 ve 1000 y1l tekerrürlü taşkın değerleri maksimum olabilirlik ve L-momentler yöntemlerine göre hesaplanmış ve hem hesaplanan bu değerler hem de dağılım parametre değerlerinin alt ve üst sınırlarının belirlenmesi suretiyle belirsizlik analizi gerçekleştirilmiş, hesaplanan parametre ve kuantil değerlerinin sınırlar içerisinde kaldığı görülmüştür. Son olarak 2, 5, 10, 25, 50, 100, 200, 500 ve 1000 yıl tekerrürlü taşkın debileri yıllık maksimum değerler üzerinden taşkın frekans analizi yapılarak elde edilmiş ve eşik üstü pikler yöntemine göre bulunan değerlerle karşılaştırması gerçekleştirilmiştir.

Elde edilen sonuçlara göre eşik üstü piklerin analizi ile elde edilen taşkın tahminlerinin yıllık maksimumların analizi ile elde edilen taşkın tahminlerine kıyasla düşük tekerrür aralıklarında daha küçük, büyük tekerrürlerde ise (500 ve 1000 yıl) tahminlerin birbirine nispeten yakın olduğu görülmüştür. Yıllık maksimum seriler eşik üstü pik serileri ile karşılaştırıldığında her yıl için bir adet veri olmak üzere daha az sayıda verinin kullanılmasıyla iliş̧ili kısıtlı veri uzunluğu bir eksiklik olarak karşımıza çıkmakta, eşik üstü pikler yönteminde yılda gözlenmiş taşkın pik sayısı birden fazla olabildiğinden daha uzun veri seti ile çalışma imkânı doğmaktadır. Ancak eşik üstü pikler yönteminde de eşik değerin belirlenmesi için genel geçer, uygulamada kolaylık sağlayacak bir rehber bulunmaması pratikte kullanılmasını kısıtlayıcı önemli bir etken olarak görülmektedir. Diğer yandan eşik üstünde kalan serinin bağımsız olma koşulunun da mutlaka sağlanması gerekmektedir. Özellikle tekerrür aralığı küçük seçilebilecek tasarım projelerinde, hidrolik yapının büyüklüğü, amacı, tipi gibi özelliklerine göre belirlenebilecek belli tekerrürler için taşkın debilerinin, her iki yöntemle de hesaplanarak karşılaştırılması önerilmektedir.

\section{Kaynaklar}

Anlı A.S., (2006), Giresun Aksu Havzası maksimum akımlarının frekans analizi, Akdeniz Üniversitesi Ziraat Fakültesi Dergisi, 19(1), 99-106.

Anlı A.S., Apaydin H., Ozturk F., (2007), Regional flood frequency estimation for the göksu river basin through L-moments, International Congress on River Basin Management Proceedings, General Directorate of Turkish State Hydraulic Works, 22-24 March, Gloria Golf Resort Hotel, Belek, Antalya, ss.424-438.

Bayazıt M., Önöz B., (2004), Türkiye’deki en büyük taşkınların zarf eğrileri, İMO Teknik Dergi, 3125-3130.

Bayazıt M., Önöz B., (2008), Taşkın ve kuraklık hidrolojisi, İstanbul Teknik Üniversitesi, Nobel Yayın No: 1334, İstanbul, 259ss.

Bayazıt M., Shaban F., Önöz B., (1997), Generalized extreme value distribution for flood discharges, Turkish Journal of Engineering and Environmental Sciences, 21(2), 69-73.

Bezak N., Brilly M., Šraj M., (2014), Comparison between the Peaks-Over-Threshold method and the annual maximum method for flood frequency analysis, Hydrological Sciences Journal, 59(5), 959-977.

Buishand T.A., (1989), The partial duration series method with a fixed number of peaks, J. Hydrol., 109(1-2), 1-9.

Büyükkaracığan N., Kahya E., (2007), Taşkın frekans analizinde kullanılan değişik dağılımların Konya Havzası yıllık pik akım serilerine uygulanıp karşılaştırılması, Uluslararası Küresel İklim Değişikliği ve Çevresel Etkileri Konferansı Bildiriler Kitabı, Konya Büyükşehir Belediyesi KOSKİ Genel Müdürlügü, Konya, ss.279-286.

Cunnane C., (1973), A particular comparison of annual maxima and partial duration series methods of flood frequency prediction, Journal of Hydrology, 18(3-4), 257-271.

Cunnane C., (1979), A note on the Poisson assumption in partial duration series models, Water Resources Research, 15(2), $489-494$.

Davison A.C., Smith R.L., (1990), Models for exceedances over high thresholds, J.Royal Statist. Soc. B., 52(3), 393-442.

Ekanayake S.T., Cruise J.F., (1993), Comparisons of weibull- and exponential-based partial duration stochastic flood models, Stochastic Hydrol. Hydraul., 7(4), 283-297.

Haktanır T., (1991), Statistical modelling of annual maximum flows in turkish rivers. Hydrological Sciences Journal, 36(4), 367-389.

Hosking J.R.M., Wallis J.R., (1987), Parameter and quantile estimation for the generalized pareto distribution, Technometrics, 29(3), 339-349.

Hosking J.R.M, Wallis J.R., (1997), Regional frequency analysis: an approach based on l-moment, Cambridge University Press, UK.

Lang M., Ouarda TBMJ, Bobée B., (1999), Towards operational guidelines for over-threshold modeling, J. Hydrol., 225(3-4), 103117.

Lu L.H. Stedinger J.R., (1992a), Sampling variance of normalized GEV/ PWM quantile estimators and a regional homogeneity test, J. Hydrol., 138(1-2), 223-245.

Lu L.H., Stedinger J.R., (1992b), Variance of two- and three-parameter GEV/PWM quantile estimators: formulae, confidence intervals, and a comparison, J. Hydrol., 138(1-2), 247-267. 
Madsen H., (2007), Time series analysis, Chapman and Hall, CRC, 297ss.

Önöz B., (1994), Statistical tests of probability distributions for flood records, International School of Water Resources Management, NATO ASI, Defence from Floods and Floodplain Management April 26-May 6, Budapest, Hungary.

Önöz B., (1996), Tail estimators applied to longest available flood samples, Bulletin of the Technical University of Istanbul, 49, 157169.

Önöz B., Bayazıt M., (1995), Best-fit distributions of largest available flood samples, J. Hydrol., 167(1-4), 95-208.

Önöz B., Bayazıt M., (2001), Effect of the occurrence process of the peaks over threshold on the flood estimates, J. Hydrol., Cilt. 244(1-2), 86-96.

Önsoy H., (2002), Doğu Karadeniz taşkın ve heyelanları, çözüm önerileri, İMO Ankara Bülteni, Sayı 2002/6, Haziran 2002, Ankara.

Rasmussen P.F., (1991), The partial duration series approach to flood frequency analysis, Series Paper, no. 55, Inst. Hydrodyn. Hydraul. Eng., Tech. Univ. Denmark.

Ribatet M., (2011), A User's Guide to the POT Package (Version 1.4), https://cran.r-project.org/web/packages/POT/vignettes/ POT.pdf, [Erişim 01 Haziran 2019].

Ribatet M., Dutang C., (2019), POT: generalized pareto distribution and peaks over threshold, R package version 1, 1-7.

Rosbjerg D., Madsen H., (1992a), On the choice of threshold level in partial duration series, Nordic Hydrological Conference, Alta, NHP-report no. 30, 604-615.

Rosbjerg D., Madsen H., Rasmussen P.F., (1992b), Prediction in partial duration series with generalized Pareto-distributed exceedances, Water Resources Research, 28(11), 3001-3010.

Saf B., (2009), Regional flood frequency analysis using L-moments for the west mediterranean region of Turkey, Water Resources Management, 23(3), 531-551.

Seckin N., Haktanir T., Yurtal R., (2011), Flood frequency analysis of Turkey using L-moments method, Hydrological processes, 25(22), 3499-3505.

Shane R.M., Lynn W.R., (1964), Mathematical model for flood risk evaluation, J.Hydraul. Div. ASCE, 90(6), 1-20.

Silva A.T., Naghettini M., Portela M.M., (2016), On some aspects of peaks-over-threshold modeling of floods under nonstationarity using climate covariates, Stoch Environ Res Risk Assess, 30(1), 207-224.

Şarlak N., Tiğrek Ş., (2016), Noktasal taşkın frekans analizi: Göksu Nehri ve Kayraktepe Barajı vaka analizi, Gazi Üniversitesi Mühendislik-Mimarlık Fakültesi Dergisi, 31(4), 1095-1103.

Şorman A.Ü., (2004), Bölgesel frekans analizindaki son gelismeler ve Batı Karadeniz'de bir uygulama, TMMOB, IMO Teknik Dergisi, 15, 3155-3169.

Todorovic P., Zelenhasic E., (1970), A stochastic model for flood analysis, Water Resour. Res., 6(6), 1641-1648.

Topaloğlu F., (2005), Regional flood frequency analysis of the basins of the east mediterranean region, Turkish Journal of Agriculture and Forestry, 29(4), 287-295.

USWRC, (1982), United states water resources council: guidelines for determining flood flow frequency, Bull. 17B, Hydrol. Comm., Water Resour. Counc., Washington, D.C.

Wang Q.J., (1991), The POT model described by the generalized pareto distribution with poisson arrival rate, J. Hydrol., 129(1-4), 263-280. 